\title{
Erratum to: Knowledge and perceptions of asthma in Zambia: a cross-sectional survey
}

Emilia Jumbe Marsden ${ }^{1 *}$, Somwe Wa Somwe ${ }^{2}$, Chishala Chabala ${ }^{2}$, Joan B. Soriano ${ }^{3}$, Cesar Picado Vallès ${ }^{4}$ and Julio Ancochea ${ }^{3}$

\section{Erratum:}

The original version of this article [1], unfortunately contained some errors in the author list and author affiliations.

1. Name of one of the authors has an additional ' $h$ ': Julio Anchochea should read Julio Ancochea.

2. Affiliations of 3 and 4 are the same institution both authors Joan B. Soriano and Julio Anchochea should be affiliation with affiliation number 3 .

The final author list and revised affiliations should be as follows:

Emilia Jumbe Marsden1*, Somwe Wa Somwe2, Chishala Chabala2, Joan B. Soriano3, Cesar Picado Vallès4 and Julio Ancochea3.

\section{Affiliations:}

1 Pendleton Family Practice, P.O. Box 38049, Lusaka, Zambia.

2 Department of Paediatrics and Child Health, University Teaching Hospital, School of Medicine, University of Zambia, Lusaka, Zambia.

3 Instituto de Investigación Hospital Universitario de la Princesa (IISP), Universidad Autónoma de Madrid, Madrid, Spain.

4. Hospital Clinic, IDIBAPS, CIBERES, Universitat de Barcelona, Barcelona, Spain.

\section{Author details \\ ${ }^{1}$ Pendleton Family Practice, P.O. Box 38049, Lusaka, Zambia. ${ }^{2}$ Department of Paediatrics and Child Health, University Teaching Hospital, School of Medicine, University of Zambia, Lusaka, Zambia. ${ }^{3}$ Instituto de Investigación Hospital Universitario de la Princesa (IISP), Universidad Autónoma de Madrid, Madrid, Spain. ${ }^{4}$ Hospital Clinic, IDIBAPS, CIBERES, Universitat de Barcelona, Barcelona, Spain}

Received: 1 March 2016 Accepted: 4 March 2016 Published online: 24 March 2016

* Correspondence: emiliajumbemarsden@gmail.com

${ }^{1}$ Pendleton Family Practice, P.O. Box 38049, Lusaka, Zambia

Full list of author information is available at the end of the article

\section{Reference}

1. Jumbe Marsden E et al. BMC Pulm Med. 2016;16:33. doi:10.1186/s12890-0160195-3.
Submit your next manuscript to BioMed Central and we will help you at every step:

- We accept pre-submission inquiries

- Our selector tool helps you to find the most relevant journal

- We provide round the clock customer support

- Convenient online submission

- Thorough peer review

- Inclusion in PubMed and all major indexing services

- Maximum visibility for your research

Submit your manuscript at www.biomedcentral.com/submit

\section{() BioMed Centra}

